\title{
Engaging values in sustainable agriculture and food systems education: Toward an explicitly values-based pedagogical approach
}

\author{
Ryan E. Galt, a,* Department of Human and Community Development \& Agricultural \\ Sustainability Institute, University of California, Davis \\ Susan F. Clark, ${ }^{b}$ Department of Human Nutrition, Foods and Exercise, Virginia Tech \\ Damian Parr, ${ }^{\mathrm{c}}$ Sustainable Agriculture Education Association
}

Submitted 5 December 2011 / Revised 10 February and 21 March 2012 / Accepted 21 March 2012 / Published online 26 May 2012

Citation: Galt, R. E., Clark, S. F., \& Parr, D. (2012). Engaging values in sustainable agriculture and food systems education: Toward an explicitly values-based pedagogical approach. Journal of Agriculture, Food Systems, and Community Development, 2(3), $43-54$.

http://dx.doi.org/10.5304/jafscd.2012.023.006

Copyright (C) 2012 by New Leaf Associates, Inc.

\begin{abstract}
Agriculture education programs that provide integrative learning experiences that reflect the complexities, values, and challenges inherent to sustainable agriculture and food systems (SAFS) continue to evolve as faculty, staff, and students implement, experience, and modify them. Higher education institutions, especially land-grant universities, have strengths that position them to implement transformative learning and action methodologies. In this article we explore the principles, approaches, and practices consistent with integrative learning and a values-based pedagogical approach to curriculum design and

a, Corresponding author: Ryan Galt, 1309 Hart Hall, One Shields Avenue, Davis, CA 95616 USA; +1-530-754-8776; regalt@ucdavis.edu

b 202 Wallace Annex, Virginia Tech, Blacksburg, VA 24061 USA; +1-540-231-8768; sfclark@,vt.edu

c http://sustainableaged.org/; dmparr@ucdavis.edu
\end{abstract}

teaching specific to SAFS. By a values-based pedagogical approach, we mean paying explicit attention to the values that (1) underpin different agricultural and food systems and their governance, (2) inform and shape educational strategies and experiences, and (3) are held by different individuals in various encounters in the learning environment. A values-based approach to SAFS curriculum development, teaching, and integrative learning is dynamic rather than static. We provide illustrations of practices across the education "lifecycle" - curriculum design, implementation, and evaluation - that have used values-based pedagogy to guide the development, modification, and strengthening of SAFS curricula. Finally, we discuss some limitations and issues that arise when using such pedagogical frameworks. We conclude by challenging educators to focus on connecting values relevant to SAFS with innovative curricular practices that allow emergence of new ways of teaching, learning, and knowing for all. 


\section{Keywords}

appreciate inquiry, experiential learning, food systems, integrative learning, land-grant

universities, sustainable agriculture, values

\section{Introduction}

Universities need to be more responsive to the need to enact curricular change if we are to prepare students to understand the interconnections between rapidly changing agrifood systems and environmental, economic, and societal contexts, and to help them to act as responsible, productive, and innovative citizens in a dramatically changing world. We see movement toward these ends (see introductory article by Jacobsen et al., in this issue), and we note that today's sustainable agriculture and food systems ${ }^{1}$ (SAFS) educational landscape continues to evolve as faculty, staff, students, and administrators actively devise strategies to create learning contexts that better reflect their values and goals than does the current context. Whether we create new programs or modify existing ones, there appears to be an emerging consensus that fundamental changes are necessary in both what and how we teach (Boyer Commission, 1998; National Academy of Sciences [NAS], 2009; Osborne, 2007). In this paper, we discuss our experiences with formal educational opportunities that reflect the complexities and current and future challenges inherent to SAFS.

The National Academy of Sciences (NAS) (2009) report Transforming Agricultural Education for a Changing $W$ orld offers nine recommendations for transforming agricultural and life science education to better address our agricultural systems' need to adapt to rapidly changing social and biophysical environments. The integrated, interdisciplinary learning strategy advocated by the report's authors implies a need to shift teaching methodology and curriculum design. With integrated learning, students not only learn theory but also gain authentic experiential practice and are able to integrate theory and practice as praxis. Likewise, educators, practitioners, and employers understand

\footnotetext{
${ }^{1}$ We refer to sustainable agriculture and food systems (SAFS) education in a similar but not synonymous way as our colleagues who refer to sustainable agriculture (SA) education.
}

that SAFS education for undergraduates should provide diverse opportunities to examine complex problems from multiple perspectives, connect theory and action inside and outside the classroom, and contend with the ethical implications and complex realities surrounding SAFS (Parr, Trexler, Khanna, \& Battisti, 2007).

Institutions of higher education have recently developed different learning environments that challenge conventional modes of teaching and extend beyond traditional academic boundaries, i.e., experiential, interdisciplinary, systems-based education (Boyer Commission, 1998; Francis, Leiblein, Helenius, Salomonsson, Olsen, \& Porter, 2001; Huber \& Hutchings, 2004; Kolb, 1984; Markus, Howard, \& King, 1993; Newell, 2001; Parr $\&$ Van Horn, 2006). A recurring theme found in the SAFS educational literature concerns the valuable role of community engagement; community-based social learning is becoming a more popular way of engaging students and cultivating responsive, reflective, and flexible learning environments (Aaker, 2007; Emery, Flora, \& Fey, 2006; Francis et al., 2001; Lieblein, Østergaard \& Francis, 2004). Specifically within land-grant universities (LGUs), many students and faculty members are creating momentum for achieving changes similar to those outlined in the NAS 2009 report, and the number of institutions with such SAFS programs continues to grow (Sustainable Agriculture Education Association [SAEA], 2011).

Most SAFS programs now embrace the notion that sustainability is inherently based on values, with increasing recognition that the question of what is to be sustained is ultimately a value judgment (Allen, Dusen, Lundy, \& Gliessman, 1991). Yet based on our conversations at SAFS education conferences, we have noticed that many of us teaching within SAFS programs come from scientific traditions in which practitioners are largely silent about the values embodied in their decisions and work because they have been trained to see science as a values-free activity (see also Leiblein, Breland, Østergaard, Salomonsson, \& Francis, 2007; Steiner and Posch, 2006). This fundamental tension - between what we have been prepared to do and what we must do - 
means that thinking through the role of values in our educational work has never been more urgent.

In this paper, we assert that a values-based approach $^{2}$ - which we define as teaching that pays explicit attention to the values that (1) underpin different agricultural and food systems and their governance, (2) inform and shape educational strategies and experiences, and (3) are held by different individuals in various encounters in the learning environment - can usefully guide the design, revision, and strengthening of SAFS teaching and curricula. We discuss the processes of designing, implementing, and evaluating SAFS curricula along the principles of values-based pedagogy, emphasizing integrative learning, where students "connect skills and knowledge from multiple sources and experiences; apply theory to practice in complex social and biophysical settings; utilize diverse and even contradictory points of view; and understand issues and positions contextually" (Huber \& Hutchings, 2004, p. 13). ${ }^{3}$ Finally, we discuss some limitations and issues that arise when using such an educational approach. We do not pretend to be subject matter experts in all of these disciplinary domains, but rather write as practitioners and lifelong learners who have grappled with these issues in our experiences in the educational system and in the programs for which we now have responsibility. Thus we do not go into great depth in all matters discussed here, but by drawing on our two programs which utilized two different bur related approaches, we aim to show how one might holistically approach the educational challenges and opportunities presented by recognizing the value-laden character of agricultural and food systems.

\footnotetext{
${ }^{2}$ We maintain that all pedagogical approaches are based on values, even if they remain implicit and unexamined. Thus, what we are advocating is an "explicitly values-based pedagogical approach," for which we use the shorthand "values-based approach" here.

${ }^{3}$ To help students develop integrative habits of mind, experiential strategies like service learning and internships invite students to make connections between coursework and community, and theory and practice. Integrative learning is further strengthened when it is infused into decisions about course design, pedagogy, and assignments, and allows time and space for dialogic processes.
}

\section{Values and Educational Praxis: Challenges and Ways Forward}

Values are a set of interpretations or beliefs concerning things of importance. They are socially constructed and personally developed within social contexts, becoming extensions of our subjective viewpoints in that they are personal judgments of what matters. Educational institutions by their very nature provide a context in which students' values and ethical development are unavoidably influenced (Berkowitz, 1997; Colby, Ehrlich, Beaumont, \& Stephens, 2003). Scholarly work is replete with arguments for and evidence about how our nation's democracy and our world's shared future depend on a more knowledgeable, civically engaged, and globally responsible citizenry (Association of American Colleges and Universities [AAC\&U], 2008; AAC\&U, 2010; Dey, Barnhardt, Antonaros, Ott, \& Holsapple, 2009; Hersch \& Schneider, 2005; Palmer, 2011).

The qualities needed to respond to twenty-first century conditions described in existing SAFS literature both implicitly and explicitly infer a need to shape students' academic experience through a values-based approach. If they embrace integrative learning, LGUs are potentially well equipped to help prepare students for civically engaged agriculture because of the wide range of applied disciplines taught and their commitment to communitybased outreach and engagement (Colasanti, Reau, \& Wright, 2009). Yet, despite their strengths, LGUs face significant epistemological ${ }^{4}$ challenges if they are to succeed in fulfilling their mandate as the preeminent adult agricultural education institutions in the U.S. Chief among these challenges is the tradition of positivism and the imbalanced privileging of objectivity in research and science education that we explore below.

Most debates over scientific inquiry being "value free" attempt to compress a large number of claims about objectivity into a singular concept that problematically conflates the various aspects (Daston, 1992; Lacey, 1999). Objectivity has made its way into pedagogy in the form of what prominent educator Parker Palmer calls "objectivism,"

\footnotetext{
${ }^{4}$ Epistemology refers to the rules that govern how we know what we know.
} 
often with dire consequences. Objectivism as a philosophical position "portrays truth as something we can achieve only by disconnecting ourselves, physically and emotionally, from the thing we want to know" (Palmer, 2007, p. 52). If we get too close to something, say adherents of objectivism, our subjective lives will contaminate the thing and our understanding of it, possibly biasing us toward it, thus threatening the purity of our knowledge. It is no wonder that under this epistemological perspective, values are so rarely explicitly discussed in higher education teaching, especially in the biophysical sciences (Palmer, 2007).

We argue that meeting the needs of a changing agrifood system will necessitate a shift in teaching and learning paradigms at LGUs, away from objectivism and toward approaches that deal specifically with the value-laden nature of agriculture and food systems generally (cf. Lieblein et al., 2007). In short, teaching approaches must enable students to deal with Schön's "swamp":

In the varied topography of professional practice, there is a high, hard ground which overlooks a swamp. On the high ground, manageable problems lend themselves to solution through the use of research-based theory and technique. In the swampy lowlands, problems are messy and confusing and incapable of technical solution. The irony of this situation is that the problems of the high ground tend to be relatively unimportant to individuals or to society at large, however great their technical interest may be, while in the swamp lie the problems of greatest human concern. The practitioner is confronted with a choice. Shall he/she...remain on the high ground where he can solve relatively unimportant problems according to his standards of rigor, or shall he descend to the swamp of important problems and non-rigorous inquiry? (2001, p. 191)

We believe that such fundamental reform in SAFS education must occur across the entire "life cycle" of educational programming, from curriculum design and courses, to teaching approaches and evaluation. We maintain that each of these interdependent components must be overlaid with a focus on praxis: practice informed by theories, and theories informed by practice. Thus, the sections below discuss each of these elements of the educational life-cycle by identifying theories and specific practices consistent with a values-based, integrative-learning approach. We draw upon our praxis with our two SAFS programs, a major and a minor, summarized in table 1 (next page).

We must note from the outset that we have noticed in faculty meetings regarding SAFS programs and course creation that faculty sometimes express a fear of discussing values directly in the classroom or, even more pronounced, asking students to consider the relevancy of certain values. In such discussions regarding curriculum development and teaching, most faculty members take the stance that their role is not to impose values on students. While we are sympathetic to the goal of non-imposition, we have two issues with this stance. First, logically, it does not follow that discussing values and even identifying our own values will result in an imposition of those values on our students. Creating a safe space for deliberations of deeply important matters allows for engagement without domination that coerces conversion (as we discuss vis-à-vis teaching practice, below). Second, when we look at the educational missions and goals of our campuses, they are all based on values, whether explicitly identified or not. For instance, the formally stated learning goals of one of our universities include: "Develop higher cognitive skills - Critical thinking, creativity, analytical ability" (University of California, Davis, n.d.). Such a statement suggests that the campus community has jointly agreed to value the cognitive domains of students, and to intentionally develop them. By asking our students to learn about, practice, and, ultimately, conform to academic norms, we are cultivating certain values and virtues, and not others. The battles of religious versus scientific authority over the last few centuries have often been about the values underlying epistemology on the one hand, conforming to orthodox religious perspectives because it is what the powerful say is true, versus the critical questioning and probing of 


\section{Table 1. Comparison of Two Sustainable Agriculture and Food Systems Programs}

\begin{tabular}{|c|c|c|}
\hline Characteristics & Major & Minor \\
\hline $\begin{array}{l}\text { Curriculum } \\
\text { Development }\end{array}$ & $\begin{array}{l}\text { Interdisciplinary Curriculum Committees: Faculty } \\
\text { ( } 8 \text { departments), students; Delphi survey of } \\
\text { academics, students, alumni, and practitioners }\end{array}$ & $\begin{array}{l}\text { Interdisciplinary Curriculum Task Force: Faculty ( } 8 \\
\text { departments), students, practitioners, NGOs, } \\
\text { outreach and dining garden staff }\end{array}$ \\
\hline Guiding Values & $\begin{array}{l}\text { - Interdisciplinary depth of knowledge } \\
\text { - Experiential learning, integrating theory and } \\
\text { practice. } \\
\text { - Systems thinking } \\
\text { - Skill development, practical and social skills } \\
\text { - Linking real-world with classroom } \\
\text { - Community building, on and off campus } \\
\text { - } \text { Adaptive curriculum management }\end{array}$ & $\begin{array}{l}\text { - Ecological stewardship and praxis } \\
\text { - Strong local economies } \\
\text { - Healthy people and communities } \\
\text { - Food security/sovereignty } \\
\text { - Collaborative teaching } \\
\text { - Experiential-integrative learning } \\
\text { - Civic engagement/democratic participation }\end{array}$ \\
\hline \multirow{3}{*}{$\begin{array}{l}\text { Curriculum } \\
\text { Theoretical } \\
\text { Frameworks }\end{array}$} & \multicolumn{2}{|c|}{ Major and Minor } \\
\hline & \multicolumn{2}{|c|}{$\begin{array}{l}\text { - Social Constructivisma } \\
\text { - Experiential Learning } \\
\text { - }{ }^{\mathrm{b}} \\
\text { - } \text { Critical Theory }^{\mathrm{d}} \\
\text { - } \text { Participatory Learninge } \\
\text { - } \text { Action Research }^{\mathrm{e}}\end{array}$} \\
\hline & $\begin{array}{l}\text { Major } \\
\text { - Competency developmentg }\end{array}$ & $\begin{array}{l}\text { Minor } \\
\text { - Value-based model }{ }^{\mathrm{h}} \\
\text { - } \text { Appreciative Inquiryi } \\
\text { - Community capitals }\end{array}$ \\
\hline $\begin{array}{r}\text { Experiential } \\
\text { Teaching } \\
\text { Activities }\end{array}$ & $\begin{array}{l}\text { - Internships } \\
\text { - Fieldwork } \\
\text { - Applied production classes } \\
\text { - Capstone class with applied team research } \\
\text { project } \\
\text { - Student Farm }\end{array}$ & $\begin{array}{l}\text { - Community partner fieldwork } \\
\text { - Food system case-study analysis } \\
\text { - Capstone class: Community action projects with } \\
\text { NGO and community-based organizations } \\
\text { - Participatory learning and problem-based } \\
\text { inquiry: e.g., learning circles. }\end{array}$ \\
\hline Evaluation & $\begin{array}{l}\text { - Competency self-assessments } \\
\text { - Peer reviews of team performance } \\
\text { - Reflective essays } \\
\text { - Portfolios }\end{array}$ & $\begin{array}{l}\text { - } \text { Critical reflection statements } \\
\text { - Assignment-based assessment } \\
\text { - Peer- and self-assessments } \\
\text { - Assessment-based portfolios } \\
\text { - Faculty-student-community partner evaluation }\end{array}$ \\
\hline
\end{tabular}

a Vygotsky, 1978; b Kolb, 1984; c Mezirow, 2000; d Habermas, 1987; e Pretty, 1995; f Bawden, 1990; g Raven, 2001; Weik et al., 2011; ${ }^{\text {h }}$ Aaker, 2007; i Cooperrider et al., 2008; j Emery et al., 2006

various objects of study and the taking of empirical data seriously that is highly valued in most quarters of the academy. This means that values always underlie the academic enterprise, specifically guiding its ways of inquiry and both interpretive and empirical knowing.
Furthermore, campus mission statements imply that their faculty consider it insufficient for their students to cultivate academic values in isolation. In fact, universities commonly espouse cultivation of "virtues" or "values," which includes taking ethical stances, including resolution through 
nonviolent means, treating people as ends and not merely as means, etc. Taking our two campuses, UC Davis and Virginia Tech, these include ethics, responsibility, honor, tolerance, mutual respect, empathy, freedom of inquiry, personal and institutional integrity, and a culture of continuous improvement (University of California, Davis, n.d.; Virginia Tech, n.d.). Deeply unethical things can happen when the quest to know is disconnected from a deep commitment to the well-being of others, as numerous examples of medical research, such as the Tuskegee syphilis experiments, make clear (Caplan, 1992; Fairchild \& Bayer, 1999). We cannot shy away from ethical commitments, our values, and others' values, even if they make us uncomfortable. Rather, we need ways to productively engage with questions of values.

\section{Curriculum Design}

In our experiences, designing a curriculum using a values-based approach should start by seeking out multiple and divergent perspectives, worldviews, and paradigms. These differences cannot be reduced merely to correct/incorrect, true/false views of the world and things within it. Rather, many of these differences are underpinned by different value systems, including their ethical and moral dimensions, as well as different

epistemological commitments.

It is useful to view SAFS education as having a broad constituency, both internal and external to the university. Internally, in programs created by faculty and students from different disciplines, discussions around what is required in a SAFS curriculum need to be guided by openness and interest in the importance of other disciplines and ways of knowing. There are tensions in that those involved have a tendency to push for their discipline being represented within the curriculum; this can lead faculty to create an imposing curriculum, manifesting the feeling that it has to cover all the bases. Externally, everyone is sustained by food, and in a democratic society everyone should have a say in food governance. There are also stakeholders who can contribute to designing SAFS education because they have more detailed knowledge of components of agriculture and the food system, including those who work in the food system, academics, current students, former students, community-based organizations, nongovernmental organizations (NGOs) and government agencies involved in SAFS work. Both internally and externally, individuals within these various positions often have diverging perspectives on a range of issues related to sustainability, especially regarding the values that currently underlie, as well as should underlie, the food system. Resolving the issues stemming from these diverging perspectives requires consensus-building across these diverse constituencies and ways of knowing. These issues can be solved or at least highlighted through methods like participatory research used by development practitioners and some social scientists, as these include facilitating group processes such as elucidating different perspectives (Pretty, Guijt, Thompson, \& Scoones, 2002). Our two programs, for example, engaged students, community partners, and faculty in efforts to inform and shape the curriculum.

Although our programs' curriculum design processes were conceptualized prior to the release of the NAS (2009) report, they both align strongly with its recommendations and those of the $A A C \& U$ that educators better prepare students for civic responsibility and engagement. This speaks to the current milieu and emerging discourse within the SAFS world. Both programs have created space to think holistically about SAFS, connected program values to empirical inquiry, enhanced critical and systems-level thinking, and cultivated social and cultural knowledge regarding healthy SAFS practices. Some scaffolding frameworks that anchor these programs include competency frameworks, appreciative inquiry, and experiential learning through fieldwork in community action projects, which we briefly explain below.

Competency frameworks, which identify the competencies (functionally linked knowledge, skills, and attitudes) that should be developed from particular educational experiences, and can be applied in other contexts, can act as the structure around which curriculum goals are developed and learning activities designed. Emerging consensus exists around the idea that normative competencies are vitally important to sustainability education (Galt, Parr, \& Jagannath, in press; Wiek, 
Withycombe, \& Redman, 2011). As we anticipate futures based on current trends and countertrends, the question of what should be and who should shoulder the cost is always central, and debates over this depend on competing values, not merely empirics. Wiek et al. define normative competence vis-à-vis sustainability as:

the ability to collectively map, specify, apply, reconcile, and negotiate sustainability values, principles, goals, and targets. This capacity enables individuals to, first, collectively assess the (un-)sustainability of current and/or future states of socialecological systems and, second, to collectively create and craft sustainability visions for these systems. (2011, p. 209)

This capacity requires learners to acquire normative knowledge, including concepts of ethics, equity, justice, and social-ecological integrity, and methods like structured visioning and multicriteria assessment.

Appreciate inquiry is a form of action research that attempts to advance the development of an organization or system, including curriculum (Cooperrider, Whitney, \& Stavros, 2008). Current models of curricular design are typically deficitbased; the gap between current performance and desired performance is analyzed and new instruction is designed to fill that gap. In contrast, appreciate inquiry (AI) methodology elucidates learners' values and maintains that they go beyond acquiring knowledge to become knowledge producers. Furthermore, AI supports a valuesbased SAFS curriculum planning-teaching-learningassessment feedback cycle.

Incorporating AI into curriculum planning teams and course projects can become a blueprint for how to produce the organizational change needed to support values-based SAFS education. AI begins with researchers and/or practitioners identifying examples of the system at its best - its highest values and aspirations - followed by what is applicable (to the system in which the inquiry takes place and can be validated in action), provocative (by creating knowledge, models and images that are compelling to system members and provoke people to take action), and finally collaborative (since system members must be part of the design and execution of the inquiry). AI processes result in new knowledge, models, and theories that serve as generative metaphors that can compel new action. A focus on changing how people think instead of what people do, and a focus on supporting self-organizing change processes that flow from new ideas rather than leading to implementation of directives, appear to be key contributors to AI-affected change.

Fieldwork integrated into curriculum offers a wide range of important integrative learning opportunities. In some cases it allows students to actively participate in thoughtfully organized service-orientated experiences that meet the articulated needs of a civic agriculture stakeholder and/or initiative in a real community context. Fieldwork focused on community projects that is research- or action-based requires students to seek rigorous answers to questions in the context of a specific social and physical location within the food system. Having structured opportunities for students to dialogue with people outside the classroom and asking them why they do what they do allows students to see other perspectives and discover what values drive people to do things, and how these values often conflict with existing societal arrangements. As Allen (2010, p. 298) notes, "Local food efforts are generally embedded in and must act within social structures that may be contrary to their ideals and values." Seeing these efforts, and the larger-scale constraints upon them, gives students the opportunity to attempt reconciliation of contradictions between what is and what they think and feel should be. Thus, designing curriculum around fieldwork is an important element of values-based pedagogy.

\section{Teaching Practice}

The classroom is a microcosm of the external community in important ways - for example, lines of social difference and different socialization experiences can create tension, but also rich learning opportunities if handled well - and how we conduct our classes reflects our values and conceptions of proper human relationships (hooks, 1994). It can be paralyzing to seriously consider the 
question: Is the way I teach a true reflection of my values, and does it serve my ultimate goals for this class, society, my students, and myself? But posing these kinds of questions can also provide liberation from rote tradition if it encourages sympathetic self-reflection that spurs changes in practice (Palmer, 2007).

Our main principles in teaching from a valuesbased pedagogical approach are that we need to (1) highly value our students as whole people and adults, with their own subjective domains and values, and (2) identify the values that underlie our teaching. Instead of fearing encounters with individuals who hold different belief and value systems than us, we can demonstrate our respect, and even a need, for accepting our differences (Palmer, 2007). For example, learning based on inclusive deliberation, from divergence to convergence and back again, is a process that never ends, but rather permeates the human endeavor to know, and is an ethos of democratic societies. Palmer argues that truth, in all modes, comes out of a complex process of shared inquiry - in short, a community of truth. This is at the heart of all academic research endeavors as well, formalized in processes like peer review. A community of truth is built around "an image of knowing that embraces both the great web of being on which all things depend and the fact that our knowledge of those things is helped, not hindered, by our being enmeshed in that web" (Palmer, 2007, p. 101). This is similar to Bain's (2004, p. 47) conclusion that the best teachers make this kind of inquiry the center of the classroom experience by cultivating a "natural critical learning environment." In this context, knowledge advances through conflict - not competition - which is "open and sometimes raucous but always communal, a public encounter in which it is possible for everyone to win by learning and growing" (Palmer, 2007, p. 106). Below we highlight a few practices that help cultivate these integrative teaching and learning

\footnotetext{
5 This involves embedding the skills and information we want to teach in assignments through questions and authentic tasks students should find fascinating, and through challenging students to rethink assumptions and examine their mental models of reality and how they came into being.
}

interactions. We cannot do justice to the array of practices available through the subset that we have used, although we note additional practices in table 1 and point to a number of available resources (Bain, 2004; Bean, 1996; Palmer, 2007; Pretty et al., 2002; Weimer, 2002).

Dialogue-based inquiry blended with appreciative inquiry generates "open space" where students can begin unraveling the basic assumptions surrounding agricultural and food issues through dialogue and consensus. Ultimately this can generate a more in-depth and authentic understanding of the values-laden concerns intrinsic to SAFS. Such practice enables students to become active learners and facilitates their academic development, personal growth, and civic engagement.

Collaborative, interdisciplinary teaching promotes sharing of knowledge between faculty, students, and community partners, expanding everyone's skills and knowledge about SAFS issues and thus benefiting the greater community (Clark \& Button, 2011; Newell, 2001). When students are asked to integrate different and often conflicting viewpoints, they frequently show greater knowledge and understanding of the subjects studied and make better decisions as a result (Johnson, Johnson, \& Smith, 2000). Furthermore, teaching collaboratively can expand intellectual capacity in ways that transfer new knowledge via other scholastic activity (Newell, 2001). However, we note that the practice of collaborative teaching takes serious commitment from key actors, especially faculty and administrators.

\section{Evaluation}

An important question remains about how we assess the outcomes of these kinds of educational praxis, as their very purpose is often qualitatively different from producing students who are masters of a tightly defined, specialized disciplinary knowledge (Boix Mansilla \& Dawes Duraising, 2007). Base on our experiences, evaluation is a fundamental, yet commonly undervalued, piece in the pedagogical puzzle. When we take our teaching as seriously as our research scholarship, that is, we treat it as a serious intellectual endeavor, it means asking critical questions about its success or limitations, and gathering data to answer these questions 
(Bain, 2004). Our experiences suggest that both faculty praxis and student learning can improve considerably, and in some cases rapidly, due to more holistic evaluation efforts.

Although we deal with a values-based approach linearly here - from design to teaching practice to evaluation - we note the importance of making educational praxis an iterative cycle, from design to implementation to evaluation to (re)design, to restart the cycle anew. For us, using evaluation that takes values seriously has meant that students should be able to ask what it is that they value and how their education serves and/or does not serve their interests. Ultimately, this would mean that students help create the questions and criteria by which their learning and formal educational activities are evaluated. Thus we briefly discuss a number of models relevant to the task of evaluating values-based education, highlighting their relative strengths and weaknesses. We move from those that follow the principles outlined above most weakly to those that align most strongly. However, there are no perfect evaluation methods, so we must make tradeoffs between intensity of data collection and analysis efforts, resources available, and intent of the evaluation (e.g., comprehensive curriculum evaluation vs. assessing specific assignments, internal communication versus external accreditation, etc.) (Patton, 2002). Many such methods have been developed; we cannot list them exhaustively, but rather point our readers toward some available resources.

Standardired evaluations used within higher education attempt to address the question of overall student learning. Because most institutions limit who is allowed to see which evaluations (the assessed faculty can see them, but their students and colleagues outside their unit and merit committees cannot), the results tell us very little in comparative context, that is, how well students are learning in these kinds of classes relative to classes using other kinds of instruction methods. Generally, these evaluations are not sufficient for the task at hand, "unless one believes that all varieties of good teaching can be crammed into the scales of a survey questionnaire" (Palmer, 2007, p. 96).
Customized evaluations, created by participating students and/or faculty members, allow evaluation questions to be tailored to the circumstances of the class. These kinds of assessments can require a range of time to perform and can employ a number of methods, including surveys, some of which can allow participants to shape the content of the survey. These evaluations can be strengthened by using independent campus centers focused on teaching and learning outcomes, available on most campuses, as this allows for a third-party data collector.

Reflective essays are assignments that require students to reflect on their learning as a personal experience by connecting their interests, values, and development with other cognitive and affective dimensions of learning. As such, they can serve dual purposes. First, they complete the learning cycle of experiential learning, meaning that it is not just experiences that help us learn, but, crucially, reflection upon those experiences (Dewey, 1938; Kolb, 1984). Second, reflective essays provide datarich windows into students' learning experiences to see how values influence student learning within classes and across a curriculum as a whole (Galt, Parr, Van Soelen Kim, Beckett, Lickter, \& Ballard, in press).

Self-assessments, wherein students are taken to be valid sources of both their own value systems and of self-knowledge, arise from critical pedagogy (Fernández-Balboa, 2007). The faculty at Alverno College in Milwaukee has done a considerable amount of work conceptualizing, refining, and practicing this model, resulting in an engaged praxis that they clearly communicate to students and outsiders (Alverno College Faculty, 1994; 2000). In our own practice, we have combined selfassessments with competency development frameworks so that students self-assess their development across dozens of competencies at different stages in courses (Galt, Parr, Van Soelen Kim, et al., in press); we are currently working to integrate self-assessments across the curriculum. Similarly, peer-to-peer and external advisory board assessments can give students greater responsibility for their learning and autonomy to better understand the real world. 


\section{Conclusions}

The NAS (2009) report recommends that we "situate" agricultural instruction at institutions of higher learning in ways that focus on integrative learning and its outcomes in order to have graduates who are competent in connecting and applying knowledge and skills from multiple sources to address issues in real-world settings. This requires moving away from the paradigm of positivism, and its corollary of objectivism in the classroom, and toward more experiential, interdisciplinary, and systems-based approaches to education.

We believe that these approaches are deeply enriched when values become a guiding element and an object for deliberation. When learning and teaching methodologies prompt faculty and student reflection and deliberation upon the multiple values that influence and shape SAFS, these methods can further students' education. They do this by challenging them via participatory dialogue, raising awareness about thought and language, developing analytical skills, and facilitating their increased agency through civic action. In our own experiences, the values-based pedagogical approach described above has been a crucial element in promoting democratic practice and successfully transforming students into lifelong, critically reflective learners who practice social and environmental responsibility and civic engagement within local and global communities (see also Galt, Parr, Van Soelen Kim, et al., in press). By developing innovative SAFS educational programs that engage values directly — by examining how they underpin food, agricultural, and social systems; how they underpin pedagogy; and the differences and similarities in values held by different individuals and groups — we strongly believe that teaching will advance learning outcomes essential for responsible citizenship.

Moving in this direction will require commitment from individuals and groups within LGUs who see the need to deal with Schön's (2001) "swamp" of complex problems that matter greatly to society but that cannot be addressed through specialist and technical approaches alone, and want to help prepare others to do the same. The work will also support the integrity of LGUs, as a deliberation on values will be essential for charting their future course and ensuring they meet their mission of serving the public good. More appropriate educational methodologies that deal with the complexities of SAFS, including being explicit about values, will facilitate the emergence of more powerful ways of meeting the challenges and opportunities of agriculture and food systems for all peoples, a charge LGUs should still take seriously. While potentially frightening, making values - especially those that conflict with economic instrumentalism and efficiency - an explicit underpinning of educational activities and an explicit focus of critical attention yields large rewards, and is crucially important given the challenges of today.

\section{References}

Aaker, J. (2007). The Heifer Model: Cornerstones values-based development. Little Rock, Arkansas: Heifer Project International.

Allen, P. (2010). Realizing justice in local food systems. Cambridge Journal of Regions, Economy and Society, 3(2), 295-308. http://dx.doi.org/10.1093/cjres/rsq015

Allen, P., Dusen, D. V., Lundy, J., \& Gliessman, S. (1991). Expanding the definition of sustainable agriculture. American Journal of Alternative Agriculture, 6(1), 34-39. http://dx.doi.org/10.1017/S0889189300003787

Alverno College Faculty. (1994). Student assessment-aslearning at Alverno College. Milwaukee, Wisconsin: Alverno College Institute.

Alverno College Faculty. (2000). Self-assessment at Alverno College. Milwaukee, Wisconsin: Alverno College Institute.

Association of American Colleges and Universities [AAC\&U]. (2008). College learning for the new global century. Washington, D.C.: Author.

Association of American Colleges and Universities [AAC\&U]. (2010). Developing a moral compass: What is the campus climate for ethics and academic integrity? Washington, D.C.: Author.

Bawden, R. (1990). Towards action research systems. In O. Zuber-Skerritt (Ed.), Action research for change and development (pp. 10-35). Brisbane: Centre for the Advancement of Learning and Teaching (CALT), Griffith University.

Bain, K. (2004). What the best college teachers do. Cambridge, Massachusetts: Harvard University Press. 
Bean, J. C. (1996). Engaging ideas: The professor's guide to integrating writing, critical thinking, and active learning in the classroom. San Francisco: Jossey-Bass.

Berkowitz, M. W. (1997). The complete moral person: Anatomy and formation. In J. M. Dubois (Ed.), Moral issues in psychology: Personalist contributions to selected problems (pp. 11-41). Lanham, Maryland: University Press of America.

Boix Mansilla, V., \& Dawes Duraising, E. (2007). 'Targeted assessment of students' interdisciplinary work: An empirically grounded framework proposed. The Journal of Higher Education, 78(2), 215237. http://dx.doi.org/10.1353/jhe.2007.0008

Boyer Commission. (1998). Reinventing undergraduate education: A blueprint for America's research universities. Carnegie Foundation for the Advancement of Learning. Retrieved from http://www.naples.cc. sunysb.edu/Pres/boyer.nsf/on

Caplan, A. L. (1992). Twenty years after: The legacy of the Tuskegee syphilis study. Hastings Center Report, 22, 29-40. http://dx.doi.org/10.2307/3562946

Clark, B. \& Button, C. (2011). Sustainability transdisciplinary education model: Interface of arts, science, and community (STEM). International Journal of Sustainability in Higher Education, 12(1), 41-54. http://dx.doi.org/10.1108/14676371111098294

Colasanti, K., Wright, W., \& Reau, B. (2009). Extension, the land-grant mission, and civic agriculture: Cultivating change. Journal of Extension, 47(4), 1-10.

Colby, A., Ehrlich, T., Beaumont, E. \& Stephens, J. (2003). Educating citizens: Preparing America's undergraduates for lives of moral and civic responsibility. San Francisco: Jossey-Bass.

Cooperrider, D. L., Whitney, D., \& Stavros, J. M. (2008). Appreciative inquiry bandbook. Brunswick, Ohio: Crown Custom Publishing, Inc.

Daston, L. (1992). Objectivity and the escape from perspective. Social Studies of Science, 22(4), 597-618. http://dx.doi.org/10.1177/030631292022004002

Dewey, J. (1938). Experience and education. New York: The Macmillan Company.

Dey, E. L., Barnhardt, C. L., Antonaros, M., Ott, M. C., \& Holsapple, M. A. (2009). Civic responsibility: What is the campus climate for learning? Washington, D.C.: Association of American Colleges and Universities.

Emery, M., Fey, S., \& Flora, C. (2006). Using community capitals to develop assets for positive community change. CD Practice, 13, 1-19. Retrieved from http://www.comm-dev.org/commdev/ collection $/ 2006 \% 2013$.pdf
Fairchild, A. L., \& Bayer, R. (1999). Uses and abuses of Tuskegee. Science, 284(5416), 919-921. http://dx.doi.org/10.1126/science.284.5416.919

Fernández-Balboa, J.-M. (2007). Dignity and democracy in the college classroom: The practice of student self-examination. In R. A. Goldstein (Ed.), Useful theory: Making critical education practical (pp. 105-128). New York: Peter Lang.

Francis, C. A., Leiblein, G., Helenius, J., Salomonsson, L., Olsen, H. \& Porter, J. (2001). Challenges in designing ecological agriculture education: A Nordic perspective on change. American Journal of Alternative Agriculture, 16(2), 89-95. http://dx.doi.org/10.1017/S0889189300008985

Galt, R. E., Parr, D. M., \& Jagannath, J. (In press). Facilitating competency development in sustainable agriculture and food systems education: A selfassessment approach. International Journal of Sustainable Agriculture.

Galt, R. E., Parr, D. M., Van Soelen Kim, J., Beckett, J., Lickter, M., \& Ballard, H. L. (In press).

Transformative food systems education in a landgrant college of agriculture: The importance of learner-centered inquiries. Agriculture and Human Values.

Habermas, J. (1987). Theory of communicative action, volume two: The critique of functionalist reason. Boston: Beacon Press.

Hersh, R. H., \& Schneider, C. G. (2005). Fostering personal and social responsibility on college and university campuses. Liberal Education, 91(3), 6-13. hooks, bell. (1994). Teaching to transgress: Education as the practice of freedom. New York: Routledge.

Huber, M. T., \& Hutchings, P. (2004). Integrative learning: Mapping the terrain. Washington, D.C.: Association of American Colleges and Universities.

Jacobsen, K. L., Niewolny, K. L., Schroeder-Moreno, M. S., Van Horn, M., Harmon, A. H., Chen Fanslow, Y. H., Williams, M. A., \& Parr, D. (2012).

Sustainable agriculture undergraduate degree programs: A land-grant university mission. Journal of Agriculture, Food Systems, and Community Development. Advance online publication. http://dx.doi.org/10.5304/jafscd.2012.023.004

Johnson, D. W., Johnson, R. T., \& Smith, K. A. (2000). Constructive controversy: The educative power of intellectual conflict. Change, 32(1), 28-37. http://dx.doi.org/10.1080/00091380009602706

Kolb, D. (1984). Experiential learning: Experience as the source of learning and development. Englewood Cliffs, New Jersey: Prentice Hall. 
Lacey, H. (1999). Is science value free? Values and scientific understanding. New York: Routledge.

Lieblein, G., Breland, T. A., Østergaard, E., Salomonsson, L. \& Francis, C. (2007). Educational perspectives in agroecology: Steps on dual learning ladder toward responsible action. NACTA Journal, 51(1), 37-44.

Lieblein, G., Østergaard, E., \& Francis, C. (2004). Becoming an agroecologist through action education. International Journal of Agricultural Sustainability, 2(3), 147-153. http://dx.doi.org/10.1080/14735903.2004.9684574

Markus, G. B., Howard, J. P. F., \& King, D. C. (1993). Notes: Integrating community service and classroom instruction enhances learning: Results from an experiment. Educational Evaluation and Policy Analysis, 15(4), 410-419. http://dx.doi.org/10.3102/01623737015004410

Mezirow, J. (2000). Learning as transformation: Critical perspectives on a theory in progress. San Francisco: Jossey Bass.

National Academy of Sciences. (2009). Transforming agricultural education for a changing world. Washington, D.C.: The National Academies Press.

Newell, W. H. (2001). Powerful pedagogies. In B. L. Smith and J. McCann (Eds.), Reinventing ourselves: Interdisciplinary education, collaborative learning, and experimentation in higher education (pp. 196-211). Bolton, Massachusetts: Anker Publishing.

Osborne, E. W. (Ed.). (2007). National research agenda: Agricultural education and communication. Gainesville, Florida: American Association for Agricultural Education.

Palmer, P. J. (2007). The courage to teach: Exploring the inner landscape of a teacher's life. San Francisco: Jossey-Bass.

Palmer, P. J. (2011). Higher education and habits of the heart: Restoring democracy's infrastructure. Journal of College and Character, 12(3), 1-6. http://dx.doi.org/10.2202/1940-1639.1823

Parr, D. M., Trexler, C. J., Khanna, N. R., \& Battisti, B. T. (2007). Designing sustainable agriculture education: Academics' suggestions for an undergraduate curriculum at a land grant university. Agriculture and Human Values, 24(4), 523-533. http://dx.doi.org/10.1007/s10460-007-9084-y

Parr, D. M., \& Van Horn, M. (2006). Development of organic and sustainable agricultural education at the
University of California, Davis: A closer look at practice and theory. HortTechnology, 16(3), 426-431.

Patton, M. Q. (2002). Qualitative research and evaluation methods (3rd ed.). Thousand Oaks, California: Sage Publications.

Pretty, J. N. (1995). Participatory learning for sustainable agriculture. World Development, 23(8), 1247-1263. http://dx.doi.org/10.1016/0305-750X(95)00046-F

Pretty, J. N., Guijt, I., Thompson, J., and Scoones, I. (2002). A trainer's guide to participatory learning and action. London: International Institute for Environment and Development (IIED).

Raven, J. (2001). The McBer Competency Framework. In J. Raven and J. Stephenson (Eds.), Competence in the learning society (pp. 121-127). New York: P. Lang.

Schön, D. (2001). The crisis of professional knowledge and the pursuit of an epistemology of practice. In J. Raven and J. Stephenson (Eds.), Competence in the learning society (pp. 183-207). New York: P. Lang.

Steiner, G., \& Posch, A. (2006). Higher education for sustainability by means of transdisciplinary case studies: An innovative approach for solving complex, real-world problems. Journal of Cleaner Production, 14(9-11), 877-890. http://dx.doi.org/10.1016/j.jclepro.2005.11.054

Sustainable Agriculture Education Association [SAEA]. (2011). Sustainable Agriculture Education Association: Academic programs. Retrieved from http://sustainableaged.org/Resources/Academic Programs/tabid/86/Default.aspx

University of California, Davis. (n.d.). Undergraduate education: Educational objectives for students. Retrieved from http://undergraduatestudies.ucdavis. edu/educational-objectives.html

Virginia Tech. (n.d.) Office of the President/University Strategic Plan: Undergraduate education. Retrieved from http://www.president.vt.edu/strategic-plan/ learning.html\#undergrad

Vygotsky, L. (1978). Mind in society. London: Harvard University Press.

Weimer, M. (2002). Learner-centered teaching: Five key changes to practice. San Francisco: Jossey-Bass.

Wiek, A., Withycombe, L., \& Redman, C. L. (2011). Key competencies in sustainability: A reference framework for academic program development. Sustainability Science, 6(2), 203-218. http://dx.doi.org/10.1007/s11625-011-0132-6 